\title{
Animal welfare benefits to mobile slaughter of cattle
}

\author{
H. Vervaecke ${ }^{1}$, I. Van Impe ${ }^{1}$, M. Debille ${ }^{1}$, P. Verbeke $^{2}$, S. Aerts ${ }^{1}$ \\ 1: Odisee University College, Agro-\& Biotechnology, Salto Research Group, Sint-Niklaas, \\ Belgium; hilde.vervaecke@ odisee.be \\ 2: BioForum Vlaanderen Antwerp, Belgium
}

The European legislation allows for national initiatives that investigate animal-friendly alternatives of live transport to the slaughter-house, such as mobile slaughter units. We reviewed the main welfare benefits in the literature with a focus on cattle. The main benefit consists of decreased transport time and elimination of transport-associated stressors such as loading and unloading, shocks and sensory stimuli of driving, injuries, fatigue, waiting time, deprivation of water, and inadequate micro-climate. Another benefit consists of the more familiar environment at slaughter on the farm allowing for reduction of stressors caused by unfamiliarity but only if the potential stressors such as people, odors, noises, light and drafts, isolation stress, regrouping stress and rough handling are reduced. Equipment and floors should be designed to reduce the risks of contracting bruises and fractures. Without transport and in case of good practice handling prior to killing, a more welfare-friendly slaughter can be realized. The Eurobarometer shows an increasing demand for products from welfare-friendly production systems. Focus group meetings with cattle breeders revealed a positive attitude towards mobile slaughter. Perceived potential benefits include low-stress, respectful, relaxed, familiar, quiet context for the animal, maximal transparency from birth till death, respectful death, reduced stress to the farmer himself, attractive marketing story fitting well with a shortcircuit and family farming strategy, potential for on-farm education on slaughter. Perceived hindrances include the present uncertainty about national legal aspects and food safety regulations, practical organization with regard to timing and location, post mortem meat processing and conservation, waste treatment, profitability of the endeavor. The unit design and practices should be carefully monitored to guarantee maximal animal welfare. For all animals, mobile slaughter, in best practice circumstances, reduces risk factors that could impair welfare of slaughter animals.

\section{Introduction}

Mobile slaughter units can be a more welfare-friendly alternative of live transport to the slaughter-house. The European Council Regulation (EC) No 1099/2009 on the protection of animals at the time of killing states "Mobile slaughterhouses reduce the need for animals to be transported over long distances and therefore may contribute to safeguarding animal welfare. (...) it is appropriate to allow Member States to establish or maintain national rules regarding mobile slaughterhouses." Also, the Eurobarometer (2015) shows an increasing demand for products from welfare-friendly production systems. We reviewed the main welfare benefits in the literature relating to mobile slaughter i.e. the reduction of transport and manipulation in a more familiar environment.

\section{Welfare problems during transport}

The FAO considers transport to be the most stressing and welfare-compromising phase in the chain of activities between farm and slaughter (FAO, 2001). During loading and unloading there is a high injury risk (Pulido et al., 2018) and bruising risk increases significantly after 30 minutes delay of unloading (Goldhawk et al. (2015) A rough driving style will result in a 
significant increase in bruises and wounds (EFSA 2011) and emotional and physical stress will be caused by excessive vibrations (Van de Water et al., (2003). At each moment of transport, independent of transport duration, a higher heart rate and cortisol value is observed (Burdick et al., 2010; Marahrens et al., 2003). Independent of age and sexe, stress increases with increasing transport time (Ponnampalam et al., 2017). Cortisol values increase progressively with transport time (Chulayo et al. 2016) Waiting time on the truck due to traffic or administration is frequent (Gonzáles et al., 2012b). Stress by transport reduces immune function making animals more susceptible to respiratory diseases (Greger, 2007). Transport results in higher excretion of gut pathogens (Barham et al., 2002) (Dewell et al., 2008).

The microclimate during transport causes the most important welfare problems (Ponnampalam et al., 2017), especially during hot summer months (Grandin \& Gallo, 2008). Without mechanical climate control, this is hard to control due to the effect of wind speed, wind direction in relation to driving direction, driving speed, number of animals, excretions, transpiration, bedding and type of walls (Dalla Villa et al., 2009; Norton et al., 2013; Bryan, 2013). Excessive heat leads to heat stress and lowered welfare (Gaughan et al., 1999), tissue damage (Chulayo et al., 2016), mortality (Cauldfield et al., 2014) and decreased immune response (Carroll et al., 2012).

Weight loss due to stress during transport is common, linked to stress and reduced water and food intake (Cernicchiaro et al., 2012). Weight loss increases with increasing temperature and rough treatment (Coffey et al. (2001)), increased waiting time (Grandin (2000) and less experience of the driver Gonzáles et al. (2012b.

Temperament, breed (Zavy et al., 1992) and individual differences (Bourguet et al., 2010) influence the stress response during transport. Younger and lighter animals show more respiratory problems following transport, and males show a higher risk of illness and mortality after transport than females (Cernicchiaro et al., 2012; Bach et al., 2004). Reactive breeds react more to separation of the herd, have higher cortisol values and are more agitated during handling, during transport and during restraint (Bourguet et al., 2015).

\section{Welfare problems due to handling}

Apart from reduction of transport, mobile slaughter offers the potential benefit of manipulation in a more familiar environment. If well managed, this allows for reduction of stressors caused by novelty and unfamiliarity. Breeds with a wild temperament and extensively kept grazers show a higher stress response, more agitated behaviour (Voisinet et al. (1997) and higher cortisol levels (Francisco et al., 2015) in unfamiliar settings. Extensively kept cattle (Burdick et al., 2010; Fisher et al., 2009; Petherick et al., 2009) and beef breeds (Cullinane et al., 2010) are handled less often than intensively kept cattle or dairy cattle cattle and are therefore less habituated to human procedures and manipulations. Stress levels in bovines will be influenced by the temperament of the animals, the quality of the infrastructure and the behaviour of the caretakers (Petherick et al., 2009; Grandin, 2006; Coombes et al. , 2014).

Regrouping with strange individuals results in more fights (Burdick et al., 2010;) in young bulls and more mounting behaviour (Broom, 2003). The risk of bruising is related to mixing unknown individuals, to inadequate handling, high numbers of animals and bad equipment and facility design (Marahrens et al., 2011). Especially bulls show a higher risk of bruising (Hultrgren et al., 2014). Higher frequencies of stress behaviour (Costa et al., 2006), prolonged waiting times in the slaughterhouse (Romero et al., 2013), rough treatment by handlers prior to slaughter (Grandin, 1996), increases the incidence of bruising. Strict control is needed to limit waiting times, regrouping stress, crowding, isolation stress or rough treatment.

\section{Cattle breeders perception of mobile slaughter}


In 2018, we organized focus group-meetings with Flemish cattle breeders $(n=3 ; n=4 ; n=6)$. They expressed a positive attitude towards mobile slaughter. Perceived potential benefits included low-stress, respectful, relaxed, familiar, quiet context for the animal, maximal transparency from birth till death, respectful death, reduced stress to the farmer himself, attractive marketing story fitting well with a short-chain and family farming strategy, potential for on-farm education on slaughter. Perceived hindrances included the present uncertainty about national legal aspects and food safety regulations, practical organization with regard to timing and location, post mortem meat processing and conservation, waste treatment and cost and profitability of the endeavor.

For animals unfit for travel, on-farm slaughter is a practical solution. For all animals, but particularly for wild or extensively kept animals, on farm slaughter without transport can be a welfare-friendly alternative to slaughter after transport. The unit design and practices should be carefully monitored to guarantee maximal animal welfare. Equipment and substrates need to be designed to reduce the risks of injuries. Regular audits and training of handlers are required to safeguard welfare (Hemsworth et al., 2011).

\section{Conclusion}

The legislative and practical framework supporting mobile slaughter pilot projects should be developed nationally to stimulate local initiatives. Strengths, weaknesses, opportunities and threats regarding animal welfare should be thoroughly evaluated. Sharing and refining of initiatives and practices will allow to optimize animal welfare.

\section{References}

Bach, S.J., McAllister, A., Mears, G.J., \& Schwartzkopf-Genswein, K.S. (2004). Long-Haul Transport and Lack of Preconditioning Increases Fecal Shedding of Escherichia coli and Escherichia coli O157:H7 by Calves. Journal of Food Protection,67(4), 672-678.

Bourguet, C., Deiss, V., Gobert, M., Durand, D., Boissy, A., \& Terlouw, C. (2010). Characterising the emotional reactivity of cows to understand and predict their stress reactions to the slaughter procedure. Applied Animal Behaviour Science, 125(1-2), 9-21.

Bourguet, C., Deiss, V., Boissy, A., \& Terlouw, E.C. (2015). Young Blond d' Aquitaine, Angus and Limousin bulls differ in emotional reactivity: Relationships with animal traits, stress reactions at slaughter and post-mortem muscle metabolism. Appl. Animal. Behav. Sci., $16,41-55$.

Broom, D.M. (2003). Causes of poor welfare in large animals during transport. Vet. Res. Commun., 27(1), 515-518.

Bryan, M. (2013). Trailer micro-climate during long-distance transport of finished beef cattle for the summer months in North America (MS Thesis). University of Saskatchewan: Canada.

Burdick, N.C., Carroll, J.A., Hulbert, L.E., Dailey, J.W., Willard, S.T., Vann, R.C., Welsh Jr., T.H., \& Randel, R.D. (2010). Relationships between temperament and transportation with rectal temperature and serum concentrations of cortisol and epinephrine in bulls. Livestock Science, 129, 166-172. 
Carroll, J.A., Burdick, N.C., Chase Jr., C.C., Coleman, S.W., \& Spiers, D.E. (2012). Influence of environmental temperature on the physiological, endocrine, and immune responses in livestock exposed to a provocative immune challenge. Domestic Animal Endocrinology, 43(2), 146-153.

Cauldfield, M.P., Cambridge, H., Foster, S.F., \& McGreevy, P.D. (2014). Heat stress: A major contributor of poor animal welfare associated with long-haul live export voyages. The Veterinary Journal, 199(2), 223-228.

Cernicchiaro, N., White, B.J., Renter, D.G., Babcock, A.H., \& Slattery, K.R. (2012). Effects of body weight loss during transit from sale barns to commercial feedlots on health and performance in feeder cattle cohorts arriving to feedlots from 2000 to 2008. Journal of Animal Science, 90(1), 1940-1947

Chulayo, A.Y., Bradley, G., \& Muchenje, V. (2016). Effects of transport distance, lairage time and stunning efficiency on cortisol, glucose, HSPA1A and how they relate with meat quality in cattle. Meat Science, 117, 89-96.

Coffey, K.P., Coblentz, W.K., Humphy, J.B., \& Brazle, F.K. (2001). Review: Basic Priciples and Economics of Transportation Shrink in Beef Cattle. The professional Animal Scientist, $17(4), 247-255$.

Coombes, S.V., Gardner, G.E., Pethick, D.W., \& McGilchrist, P. (2014). The impact of beef cattle temperament assessed using flight speed on muscle glycogen, muscle lactate and plasma lactate concentrations at slaughter. Meat Science, 98(4), 815-821.

Costa, L.N., Lo Fiego, D.P. , Tassone, F., \& Russo, V. (2006). The Relationship Between Carcass Bruising in Bulls and Behaviour Observed During Pre-slaughter Phases. Veterinary Research Communications, 30(Suppl. 1), 379-381.

Cullinane, M., O’Sullivan, E., Collins, G., Collins, D.M., \& More, S.J. (2010). A review of bovine cases consigned under veterinary certification to emergency and casualty slaughter in Ireland during 2006 to 2008. Ir. Vet. J., 63(9), 568-577.

Dewell, G.A., Simpson, C.A., Dewell, R.D., Hyatt, D.R., Belk, K.E., Scanga, J.A., Morley, P.S., Grandin, T., Smith, G.C., Dargatz, D.A., Wagner, B.A., \& Salman, M.D. (2008). Impact of Transportation and Lairage on Hide Contamination with Escherichia coli O157 in Finished Beef Cattle. Journal of Food Protection, 71(6), 1114-1118.

Dalla Villa, P., Marahrens, M., Domingo, M., Velarde Calvo, A., Di Nardo, A., Dalmau, A., Kleinschmidt, N., Truar, A., Fuentes Alvarez, C., Otero, J.L., Di Fedi, E., \& Müller-Graf, C. (2009). Project to develop Animal Welfare Risk Assessment Guidelines on Transport. EFSA Supporting Publications, 1-143.

European Council Regulation (EC) No 1099/2009 of 24 September 2009 on the protection of animals at the time of killing.

Food and Agriculture Organization (FAO) (2001). Guidelines for Humane Handling, Transport and Slaughter of Livestock - Chapter 6: Transport of Livestock. 
Fisher, A.D., Colditz, I.G., Lee, C., \& Ferguson, D.M. (2009). The influence of land transport on animal welfare in extensive farming systems. Journal of Veterinary Behavior, 4, 157-162.

European Food Safety Authority (EFSA) (2011). Scientific Opinion Concerning the Welfare of Animals during Transport. EFSA Journal, 9(1): 1966.

Eurobarometer: Attitudes of Europeans towards Animal Welfare Attitudes of Europeans towards Animal Welfare, November - December 2015

Francisco, C.L., Resende, F.D., Benatti, J.M.B., Castilhos, A.M., Cooke, R.F., \& Jorge, A.M. (2015). Impacts of temperament on Nellore cattle: physiological responses, feedlot performance, and carcass characteristics. Journal of Animal Science, 93(11), 5419-5429

Gaughan, J.B., Mader, T.L., Holt, S.M., Josey, M.J., \& Rowan, K.J. (1999). Heat tolerance of Boran and Tuli crossbred steers. Journal of Animal Science, 7(9), 2398-2405

Goldhawk, C. Janzen, E., González, L.A., Crowe, T., Kastelic, J.., Kehler, C., Siemens, M., Ominiski, K., Pajor, E., \& Schwartzkopf-Genswein, K.S. (2015). Trailer temperature and humidity during winter transport of cattle in Canada and evaluation of indicators used to assess the welfare of cull beef cows before and after transport. Journal of Animal Science, 93(7), 3639-3653.

González, L.A., Schwartzkopf-Genswein, K.S., Bryan, M., Silasi, R., \& Brown, F. (2012b). Benchmarking study of industry practices during commercial long haul transport of cattle in Alberta, Canada. Journal of Animal Science, 90(10), 3606-3617.

Grandin, T. (1996). Factors that impede animal movement at slaughter plants. Journal of The American Veterinary Medical Association, 209, 757-759.

Grandin, T. (2000). Behavioural Principles of Handling Cattle and Other Grazing Animals Under Extensive Conditions. In T. Grandin (Ed.), Livestock handling and transport (2nd edition) (pp. 63-86). Oxon: CABI Publishing.

Grandin, T. (2006). Progress and challenges in animal handling and slaughter in the U.S. Applied Animal Behaviour Science, 100(1-2), 129-139.

Grandin, T. \& Gallo, C. (2008). Cattle Transport. In T. Grandin (Ed.), Livestock handling and transport (3nd edition) (pp. 134-154). Oxfordshire: CABI Publishing.

Greger, M. (2007). The Long Haul: Risks Associated with Livestock Transport. Biosecurity and Bioterrorism: Biodefense Strategy, Practice and Science, 5(4), 301-311.

Hemsworth, P.H., Rice, M., Karlen, M.G., Calleja, L., Barnett, J.L., Nash, J., \& Coleman, G.J. (2011). Human-animal interactions at abattoirs: Relationships between handling and animal stress in sheep and cattle. Applied Animal Behaviour Science, 135(1-2), 24-33.

Hultrgren, J., Wiberg, S., Berg, C., Cvek, K., \& Kolstrup, C.L. (2014). Cattle behaviours and stockperson action related to impaired animal welfare at Swedish slauther plants. Applied Animal Behaviour Science, 152, 23-37.

Marahrens M., Von Richtofen I., Schmeidduch S., \& Hartung J. (2003). Special problems of long-distance road transports of cattle: Deutsche Tierarztliche Wochenschrift, 110(3), 120125. 
Marahrens, M., Kleinschmidt, N., Di Nardo, A., Velarde, A., Fuentes, C., Truar, A., Otero, J.L., Di Fede, E., \& Dalla Villa, P. (2011). Risk assessment in animal welfare - Especially referring to animal transport. Preventive Veterinary Medicine, 102(2), 157-163

Norton, T., Kettlewell, P., \& Mitchell, M. (2013). A computational analysis of a fully-stocked dual-mode ventilated livestock vehicle during ferry transportation. Computers and Electronics in Agriculture, 93, 217-228.

Petherick, J.C., \& Phillips, C.J.C. (2009). Space allowances for confined livestock and their determination from allometric principles. Applied Animal Behaviour Science, 117(1-2), 1-12.

Ponnampalam, E.N., Hopkins, D.L., Bruce, H., Li, D., Baldi, G., \& Bekhit, A.E. (2017). Causes an Contributing Factors to "Dark Cutting" Meat: Current Trends and Future Directions: A Review. Comprehensive Reviews in Food Science and Food Safety, 16(3), 400-430.

Pulido, M.A., Mariezcurrena-Berasain, A.M., Sepúlveda, W., Rayas-Amor, A.A., Salem, A. Z.M., \& Miranda-de la Lama, G.C. (2018). Hauliers' perceptions and attitudes towards farm animal welfare could influence the operational and logistics practices in sheep transport. Journal of Veterinary Behavior, 23, 25-32.

Romero, M.H., Uribe-Velásquez, L.F., Sánchez, J.A., \& Miranda-de la Lama, G.C. (2013). Risk factors influencing bruising and high muscle $\mathrm{pH}$ in Colombian cattle carcasses due to transport and pre-slaughter operations. Meat Science, 95(2), 256-263.

Van de Water, G., Verjans, F., \& Geers, R. (2003). The effect of short distance transport under commercial conditions on the physiology of slaughter calves; $\mathrm{pH}$ and colour profiles of veal. Livestock Production Science, 82(2-3), 171-179.

Voisinet, B.D., Grandin, T., O’Connor, S.F., Tatum, J.D., \& Deesing, M.J. (1997). Bos indicus-cross feedlot cattle with excitable temperaments have tougher meat and a higher incidence of borderline dark cutters. Meat Science, 46(4), 367-377.

Zavy, M.T., Juniewicz, P.E., Phillips, W.A., \& von Tungeln, D.L (1992). Effect of initial restraint, weaning and transport stress on baseline and ACTH stimulated cortisol responses in beef calves of different genotypes. Aust. J. Vet. Res., 53(4), 551-557. 